\title{
CRECHE E FAMÍLIA: UMA PARCERIA NECESSÁRIA
}

\author{
DAMARIS GOMES MARANHÃO \\ Faculdade de Enfermagem da Universidade Santo Amaro \\ dmaranhao@uol.com.br \\ CYNTHIA ANDERSEN SARTI \\ Departamento de Medicina Preventiva da Escola Paulista \\ de Medicina da Universidade Federal de São Paulo \\ csarti@unifesp.br
}

\begin{abstract}
RESUMO
Estudo de caso em uma creche pública, que tem como objetivo analisar relações entre famílias e profissionais que se desenvolvem no cuidado compartilhado das crianças. Apesar de esforços de profissionais para interagir com as famílias, há evidentes dificuldades na interação, devido a distintos pontos de vista. Considerando que conflitos são inerentes à vida psíquica e social e que é necessário explicitá-los e negociá-los para alcançar objetivos comuns, o artigo buscou apreender o ponto de vista dos sujeitos envolvidos no cuidado infantil. Depreendeu-se da análise que a confiança é construída com "o tempo", no processo de compartilhar o cuidado, ajustando expectativas e negociando diferentes concepções, valores e conhecimentos. Como mostraram dados da observação, conflitos não explicitados nem refletidos podem comprometer o cuidado da criança, que vivencia e percebe quando as diferenças entre a creche e a família são focos de tensão.

CRECHES - FAMILLIAS - RELAÇÕES ESCOLA-FAMIILIA - CONFLITOS
\end{abstract}

\section{ABSTRACT}

DAY CARE CENTER AND FAMILY: AN ESSENTIAL PARTNERSHIP. Case study in a public day care center aims to investigate the relationships between children's families and day care center's professionals. In spite of the efforts of professionals, there are evident difficulties in their interaction, due to different points of view. Considering that conflicts are inherent to psychical and social life and that it is necessary to explicit and negotiate them to achieve common objectives, the article searches to apprehend the point of view of the subjects involved in the child care. The analysis showed that confidence is constructed over "time", during the process of sharing the child care, adjusting expectations and negotiating different conceptions, values and knowledge. Conflicts neither explicit nor discussed might impair the care given to the child who experiences and perceives when the differences between the day care center and the family are a focus of tension. DAY CARE - FAMILY - FAMILY SCHOOL RELATIONSHIP - CONFLICT

A pesquisa na qual se baseou este artigo corresponde à tese de doutorado de Damaris Gomes Maranhão (2005), orientada por Cynthia A. Sarti. 
A crescente demanda por creches revela uma tendência da família contemporânea a buscar parceiros para conciliar cuidados e educação dos filhos pequenos e o trabalho materno.

A insuficiência de vagas em creches públicas diante da demanda, ou o elevado custo das creches particulares, não permite, na maioria das vezes, que esse serviço seja escolhido com base em princípios, valores e critérios da família, impossibilidade associada à relação assimétrica, entre usuários e instituição (Sarti, 1998).

Vários pesquisadores apontam conflitos na relação entre famílias e profissionais de creche (Haddad, 1987; Franciscato, 1996; Rossetti-Ferreira, Amorim, Vitória, 1997; Bonomi, 1998; Ingrosso, 1998; Monção, 1999; Maranhão, 2000, 2000a, 2005).

A creche, instituição marcada por um histórico assistencialista e organizada de forma improvisada e precária, está sendo ressignificada como centro de cuidado e educação infantil, de acordo com a noção do direito universal à educação. Essa ressignificação reflete-se evidentemente nas relações entre usuários e profissionais, permeadas por expectativas mútuas. As mudanças surgem não apenas na creche, mas na família e, sobretudo, nas interações entre ambas (Haddad, 2003; Amorim, Rosseti-Ferreira, 2004; Maranhão, 2005).

Apesar dos esforços de muitos profissionais de creche de interagir com as famílias, visando compartilhar a educação infantil, ainda há evidentes dificuldades de se lidar com o aspecto relacional do confronto entre os indivíduos envolvidos no cuidado da criança, dados seus pontos de vista diversos. Segundo Bonomi ( 1998) que se baseia na experiência italiana, os pais não encontram espaço para troca de experiências com a equipe da creche, mas apenas a imposição de um modelo educacional pela instituição (Bonomi, 1998).

Considerando que conflitos são inerentes à vida social e psíquica e que sua explicitação e negociação são necessárias para que os envolvidos tenham seus direitos respeitados e os objetivos comuns sejam alcançados, este artigo tem como objetivo analisar as relações entre famílias e profissionais de creche que se desenvolvem no cuidado compartilhado das crianças, buscando apreender seus pontos de vista e a forma como lidam com suas diferenças. 
Creche e família...

\section{METODOLOGIA}

Foi utilizada uma metodologia qualitativa, com base em um estudo de caso, por meio do uso de técnicas etnográficas: análise de documentos; observação do cotidiano da creche e entrevistas abertas com roteiro semi-estruturado com dez profissionais, 13 familiares e oito crianças.

trabalho de campo desenvolveu-se em uma creche pública, remanescente da rede implantada pela extinta Secretaria do Estado do Menor e mantida por uma empresa de economia mista, localizada na zona sul do Município de São Paulo, no período entre novembro de 200 I e janeiro de 2003.

Para a análise dos dados, foi construído um "esqueleto" da organização da instituição e das características socioeconômicas de seus usuários, apoiado em dados quantitativos, constituindo o que Malinowski ( 1980) nomeou "anatomia do grupo". Esse esqueleto permitiu situar os fatos cotidianos, sistematicamente observados, que, na linguagem do autor, são "a carne e o sangue", complementados pelas expressões e falas "dos nativos" que constituem o "espírito" do grupo pesquisado, contemplando as perspectivas dos profissionais, das famílias e das crianças.

A análise articulou as diferentes falas coletadas nas entrevistas, os dados da observação e os da pesquisa documental, buscando apreender o ponto de vista dos sujeitos investigados sobre o tema em questão: a relação entre famílias e profissionais no processo de compartilhar cuidados infantis. Com base na articulação dos dados, foram construídos quatro eixos temáticos de análise: a construção da parceria entre família e creche; o cuidado compartilhado entre ambas e a criança; a relação entre creche e família, vista na perspectiva da criança; e, finalmente, a complementaridade necessária entre a creche e a família para o cuidado adequado da criança. Este artigo focaliza o segundo eixo temático'.

\section{ESCOLHER A CRECHE}

Quando os pais decidem compartilhar o cuidado e a educação de um filho com profissionais de uma creche partem do conhecimento que possuem

I. O projeto desta pesquisa foi aprovado pelo Comitê de Ética em Pesquisa da Universidade Federal de São Paulo - Unifesp -, cumprindo as exigências da Lei n. 196 de 1996, do Ministério da Saúde sobre pesquisas envolvendo seres humanos. 
sobre a instituição, seja pelo contato direto com esse tipo de serviço, seja com base no que ouviram das pessoas que compõem sua rede de sociabilidade.

Os dois sentidos da creche - espaço assistencial que tem sido ressignificado como espaço educativo - co-existem e podem ser identificados nas falas e expectativas dos pais e mães, ao falarem de desconfiança e de preconceito a respeito de uma creche genérica, de insegurança e medo de partilhar o cuidado das crianças com pessoas relativamente desconhecidas, da "sensação de abandono" ao deixar o filho pela primeira vez na instituição, mas, ao mesmo tempo, da dificuldade e do alívio da conquista da vaga e das vantagens de poder contar com profissionais preparados: "A gente sente pena porque acha que está abandonando lá, e não, depois que eu vi, não é nada disso não. É um preconceito, que nem minha prima falava muito: 'Dá um dó de deixar...' Eu falo: 'Não dá dó, porque elas cuidam muito melhor que a gente' " (Mãe do Cláudio, dois anos, e de Carina, três anos).

Não se trata apenas da superação do preconceito em relação à instituição em si, mas também de uma ideologia que defende a socialização primária como tarefa exclusiva dos membros da família, sobretudo, da mãe (Chodorow, 1978; Butler, 2003; Rosemberg, 1992; Saffioti, 1992).

Para Chodorow (1978, p.60) as capacidades e aptidões das mulheres para maternagem e para obter satisfação nela estão fortemente internalizadas e psicologicamente reforçadas, e são construídas, ao longo do processo de desenvolvimento, no interior da estrutura psíquica feminina. Sendo assim, conforme Moraes (1994), as mulheres podem sentir um gozo e uma possibilidade de transcendência na maternidade. Várias mães entrevistadas revelam uma ambigüidade, fruto do desejo de cuidar diretamente dos filhos e, ao mesmo tempo, da necessidade de dar continuidade ao projeto de vida pessoal ou de aumentar a renda da família (Sarti, 1995).

Tentei voltar a trabalhar, mas, ela mamava o peito, ela não queria saber de outra coisa, era só o peito. Eu queria curtir ela um pouco, as outras não tinham mamado no peito, ela tava mamando e era tudo o que eu queria, só que a gente precisa trabalhar. (Mãe de Karen, seis anos)

$\bigcirc$ modelo tradicional de pai provedor e mãe dedicada exclusivamente aos cuidados e educação dos filhos é um desejo acalentado por alguns casais, como explica um pai: 
Creche e família...

Eu não gostaria que a minha mulher trabalhasse, gostaria que ela cuidasse da minha filha, desse estrutura emocional, afetiva, seria muito bom. Mas, infelizmente, a situação do país acaba pressionando a mulher a pensar assim: Você não pode ficar em casa o dia inteiro, enquanto o seu marido rala, ou coisa desse tipo, então, a mulher se sente, às vezes, coagida pela situação econômica do país a lutar. (Pai de Juliana, dois anos)

A primeira opção para compatibilizar os dois papéis é delegar os cuidados da criança às avós, mantendo, de certa forma, o modelo tradicional de cuidado individualizado, prestado por uma mulher, no contexto familiar.

Minha mãe não tinha condições de ficar com ela, devido à idade, então, fui obrigada a fazer isto, embora não quisesse. Eu achava que ela era muito pequena, ia completar os dois anos, além de que ela vem de uma adoção, então ela já vem com uma rejeição, uma certa carência. Você tira uma criança de um abrigo pra depois pôr numa creche! Eu sempre achei que o lugar ideal da criança é junto da mãe, mas infelizmente eu preciso trabalhar. (Mãe de Rute, três anos)

No caso, é evidente o conflito materno ao "ter" de compartilhar o cuidado da filha adotiva com os educadores da creche, o que, para ela, significa perpetuar "o abandono" de uma criança que foi retirada de um abrigo.

Amorim et al. (2004) citam que os motivos que levam os pais a colocarem os filhos na creche são diversos e contraditórios. Confirmam o que se observa nas atitudes e na fala dos familiares e profissionais, sujeitos desta pesquisa, quanto às suas diferentes concepções e sentimentos, refletidos na forma como se posicionam diante da necessidade de compartilhar os cuidados e a educação de crianças pequenas. Essas concepções e sentimentos representam, segundo as autoras, os motores do modo como os familiares promovem o contato da criança no novo espaço.

Minha situação é assim, só eu que trabalho na minha casa, meu marido não trabalha. Ele faz bico, assim. Quando aparece ele faz, quando não aparece, ele fica cuidando dela. Vai fazer uns três anos, então, quero que ele arrume um serviço. Porque, eu sozinha não dá, não tem como, o salário é pouco. Eu falei: 
eu tenho que arrumar uma creche pra ela, pra ele poder ir trabalhar. (Mãe de Tânia, três anos)

caso é peculiar. A mãe matriculou a filha na creche como estratégia para que o pai procurasse um emprego fixo e dividisse com ela o sustento do lar. Há outros casos referidos pela diretora, cujos homens são sustentados pelas mulheres há longo tempo, sem que isto represente uma troca de papéis deliberada, com base num acordo consensual entre o casal, mas sim algo que, embora permanente, é vivido como circunstancial, semelhante à situação temporária de desemprego do pai.

Antes de procurar uma creche, os pais ponderam, de um lado, as necessidades econômicas, as mudanças no contexto familiar, as carências da infância, os limites dos avós em dar conta da tarefa de compartilhar com os pais a educação e o cuidado dos netos e, de outro, as informações veiculadas na mídia sobre maus tratos de crianças em instituições ou sob a guarda de babás.

A argumentação de parentes e ou amigos sobre os riscos das diferentes opções que cada família tem para cuidar e educar os pequenos interfere na decisão de pais e mães em favor da creche, embora isso, de início, não exclua a insegurança, pois a creche ainda é percebida, por algumas famílias, como um lugar inferior à "escolinha" ou aos cuidados da "babá".

Eu achava que a gente ia colocar em uma escolinha, sabe, mais conhecida, ou então, pegar uma babá pra ficar com ela, mas aí a minha sogra falou: Não! Vamos colocar ela na creche, porque uma babá, ela vai estar sozinha com a menina, e ninguém vai poder falar o que ela fez e o que ela não fez. Na creche não, se alguém fizer alguma coisa errada, alguém vai comentar e todo mundo vai ficar sabendo. Então, é mais seguro. E ela falou sobre esta creche onde já tinha um sobrinho, o Davi. Aí, eu falei: Ah, coitada. Ela é muito pequenininha, ela nem anda, nem fala, vai sofrer muito. (Mãe da Lícia, um ano)

preconceito não incide apenas sobre a creche como instituição de cuidado infantil, mas sobre seu caráter de serviço público, percebido como de pouco crédito, pelo atendimento de baixa resolutividade e massificado, no qual o usuário se sente "mais um", como disse outra mãe. 
Creche e família...

A convivência coletiva com populações dos segmentos sociais mais pobres, característica da clientela que utiliza os serviços públicos por serem gratuitos, pode representar para os pais com melhores condições de vida que procuram o serviço uma proximidade com a diversidade social, vivida como "ameaçadora" no sentido de uma possível "contaminação" com o outro, em um país caracterizado por uma sociabilidade endógena, intraclasse e não interclasses sociais.

Pesar esses riscos com os benefícios ao desenvolvimento infantil depende da superação dos preconceitos sobre uma creche genérica, em confronto com o reconhecimento das qualidades de um serviço, em particular, com base na competência de seus profissionais.

Os familiares e os profissionais comparam um serviço com outro, pois sabem que há diversidade entre as instituições, com maior ou menor infraestrutura e qualidade de serviços. Entretanto, inscrever o filho na lista de demanda de uma creche é apenas o início de um processo que pode ser mais ou menos demorado e repleto de significados, até que se consiga a vaga.

\section{CONSEGUIR A VAGA}

No Brasil, a criança menor de seis anos de idade tem o direito à educação infantil constitucionalmente reconhecido, por meio do atendimento em creches e pré-escolas (Haddad, 2003).

Entretanto, "o divórcio entre a legislação e a realidade brasileira não é de hoje", como afirma Campos (2002, p.27), pois se prioriza a instituição de diretrizes amplas, sem prever mecanismos operacionais efetivos que garantam sua aplicação na realidade. Agravando o descompasso entre legislação e planejamento, a falta de legislação complementar e as políticas econômicas de ajuste, na fase pós-constituinte resultaram em retrocessos nas áreas sociais, atingindo setores com déficits históricos como a educação e saúde infantil, com transferência de atribuições do governo para organizações não governamentais, como ocorreu com a creche estudada.

Em 1987, em pleno debate em torno da Constituição, que seria aprovada em 1988, o Programa de Creches-Pré-escolas, da Secretaria do Estado do Menor, partiu do princípio da universalidade. Isto significava romper com a tradição de selecionar usuários de creche pelo critério socioeconômico e de trabalho materno. 
No entanto, a creche também é um direito social dos trabalhadores urbanos e rurais, conforme previsto no Art. $6^{\circ}$, inciso XXV, garantindo a igualdade de oportunidades para homens e mulheres (Brasil, 1988; Haddad, 2002). O reconhecimento dessa instituição híbrida, que atende a um duplo direito de educação infantil e de cuidado dos filhos dos trabalhadores, e a falta de uma política efetiva de ampliação de vagas e de melhora de qualidade geram contradições para os profissionais que precisam selecionar, entre todas as crianças inscritas, quais serão matriculados, uma vez que a demanda é sempre superior à oferta.

déficit crônico de creches em relação à demanda, também, pode ser analisado como falta de legitimidade da instituição pelas mesmas contradições mencionadas, com pouco investimento público e desvalorização de seus profissionais, em sua maioria, mulheres (Kramer, 2002).

número insuficiente de serviços para a infância restringe as possibilidades de escolha por parte da família, submetendo-a a uma situação de espera e interferindo na relação com a equipe, uma vez que os pais podem se sentir gratos ao conseguirem a vaga, sobretudo, quando a creche é a única opção da família, reproduzindo a idéia de um "favor", em detrimento do reconhecimento de um direito.

O princípio do direito social dos trabalhadores prevalece sobre o princípio da universalidade da educação infantil. Das 88 famílias usuárias do serviço, em 2002, quatro mães declaram-se "do lar", o que ainda é motivo de estranhamento por alguns profissionais da creche que associam o cuidado infantil ao trabalho remunerado da mãe.

Na prática, quando se trata de famílias de baixa renda, residentes longe da creche, o trabalho externo da mãe, mesmo não sendo uma prerrogativa para conseguir a vaga, viabiliza a freqüência da criança à creche, pois permite pagar o transporte diário até a instituição.

Enquanto a mãe não consegue vaga na creche ela pode tentar conciliar o trabalho e os cuidados da criança, mas, chega à conclusão que é difícil ou mesmo impossível fazer bem as duas coisas ao mesmo tempo.

A Karen ia trabalhar comigo. Aí eu falava pro meu patrão: "tem paciência, eu vou conseguir". Ele respondia: "fica tranqüila". Mas não dava, atender telefone, uma criança de um ano e meio, ela sentava lá, colocava ela no meio das coisas, 
Creche e família...

deixava lá, dava comida, olhava ela mais ou menos assim. O pai da Karen e a família dele eram contra ela vir para a creche. Eu disse: Mário, eu não posso parar de trabalhar, eu não posso, e o serviço fica prejudicado, quer dizer, eu nem produzo, percebi, nem cuido bem dela, quer dizer, eu não faço nada. Você fica no meio, não faz nem uma coisa nem outra. (Mãe de Karen, seis anos)

A alternativa é o pagamento de uma pessoa para "olhar", o que consome parte da pequena renda familiar, ou delegar os cuidados a outros filhos mais velhos, em consonância com a idéia que o trabalho fora ou dentro do lar, mesmo das crianças, é fonte de superioridade moral para os pobres. No caso das crianças, significa uma forma de proteção contra os riscos e descaminhos do mundo da rua, identificado com a desordem (Sarti, 2005).

Ainda que o cuidado infantil seja considerado prioritariamente uma função social feminina associada ao afeto, seja no âmbito familiar ou das instituições, e definida pelas relações de gênero (Scavone, 1997), há casos em que os meninos também assumem o cuidado dos pequenos, com apoio de outras mulheres, na busca de viabilizar o cuidado da família:

Quem cuidava do Edílson pra mim, era meu sobrinho de 14 anos, ele cuidava melhor que a menina. A minha cunhada comprava leite e as coisas para o meu filho e queria ficar com ele, mas eu falava não, não vou dar nenhum, se quiser me ajudar, tem que me ajudar assim e pronto. Até quando eu puder arrumar um lugar pra eles, uma creche, pra poder realmente ficar tudo comigo. Porque ficar tudo separado, é muito ruim! Eu vou trabalhar, para não ficar pedindo as coisas pra vocês. A Paula, quando meu marido morreu, ela estava com um ano. Sempre morou comigo, mas quando o pai morreu, ela foi pra Guaianazes na casa de um tio dela, e ficou lá um mês, até vir pra creche. Depois, quando eu consegui vaga pra ela, ela ficou aqui comigo direto. (Mãe de André, seis anos; Edilson, quatro anos; Paula, três anos; Dane, dez meses)

Deixar o filho por um tempo na casa de parentes ou padrinhos, ou "dar para criar" é um fenômeno estudado pela antropóloga Claudia Fonseca ( 1995). Essa "circulação de crianças", ao contrário de significar abandono, é uma alternativa das famílias pobres para garantir a sobrevivência dos pequenos. 
Para Ana, conseguir a vaga na creche significou não ter que optar entre "dar" os filhos para a cunhada ou "interná-los".

Então, eu fui procurar o fórum para internar eles e ir ver no final de semana, aí ele [o juiz] falou: "Não posso fazer isto, porque eles têm mãe e família pra fazer isto". Aí eu falei: "eu estou vendo creches, mas é uma emergência". Aí, ele falou: "então, você vai vendo as creches, depois você passa na assistente social, com a creche que você conseguiu. Aí você volta aqui que a gente dá um jeito, porque as crianças não podem ficar, porque é lei, porque a mãe arruma os filhos e depois vai internando, abandonando!" Aí eu falei: "não! Perder os meus filhos eu não vou perder!" (Mãe de André, seis anos; Edilson, quatro anos; Paula, três anos, Dane, dez meses)

Há outras creches públicas próximas à que foi campo deste estudo e algumas famílias referem ter inscrito seus filhos em várias delas ao mesmo tempo, na tentativa de conseguir a vaga, embora tenham preferência por esta.

Todo mundo fala que a creche melhor que tem é esta, da Dona Cibele. Aí, eu vim, fiquei quase três anos na luta. Na lista de espera, mas eu não consegui. Consegui agora, mas, o meu nome já estava... Eu me lembro o número, um era 237 e o outro 236. Foi Deus mesmo! Eu vou pagar todas as minhas promessas que eu tenho que pagar! Fui no "Do portão"2. (Mãe de Cláudio, dois anos e Carina, três anos)

Para os pais de Juliana, família com melhores condições socioeconômicas, conseguir a vaga também foi "um milagre".

Foi feita a inscrição, e a gente naquela expectativa. Minha filha ficava com uma vizinha enquanto minha esposa trabalhava e eu ficava à tarde e trabalhava à noite. Um dia ligaram pra mim falando: "apareceu uma vaga pra sua filha..." foi uma bênção de Deus, foi milagre, eu diria. (Pai de Juliana, dois anos)

2. Bento do Portão era um mendigo, cujo túmulo no cemitério de Santo Amaro tornou-se local de peregrinação e pagamento de promessas. 
Creche e família...

\section{A CONFIANÇA}

Os primeiros contatos entre as famílias e os profissionais são decisivos na construção do relacionamento entre ambos. As primeiras impressões dos pais podem ser confirmadas ou modificadas nos primeiros dias como usuários, ainda vulneráveis por estarem no início de uma relação com os profissionais.

Pelos relatos das mães a respeito dessa fase, observam-se preocupações relativas à separação temporária do filho, à continuidade dos cuidados com a alimentação, conforto e segurança da criança. A mãe receia que as necessidades do filho não sejam percebidas no coletivo; que os cuidados sejam diferentes de casa, que sinta fome ou seja agredido pelos outros.

Os comportamentos e as falas das mães, sobre esta fase, revelam uma luta interna entre usufruir a vaga, arduamente conquistada, e confiar que o fiIho ficará bem na creche. A sensibilidade da equipe da creche, em relação ao comportamento materno, na fase de adaptação, pode dar pistas importantes sobre a forma de ajudar ambas, mãe e criança, a começar bem a vida no novo ambiente.

A mãe avalia a atenção do profissional com seu filho e com o grupo, assim como a reação da criança ao novo ambiente: "Porque no começo, aqui, eu vi a atenção da tia. Dava uma atenção! Eu achava que ela não ia ter muita atenção, igual à que a mãe dá. As tias cuidam muito bem das crianças, nossa é, assim, uma creche muito boa" (Mãe de Tânia, três anos).

O uso da palavra "tia", para denominar o profissional, pode ser interpretado como uma expectativa da mãe de que a relação do educador com sua filha seja permeada pela afetividade, semelhante àquela de um membro da família, como a irmã da mãe ou do pai teria, uma atenção individualizada à criança, "igual à que a mãe dá”. Para Rosemberg ( 1992) e Kramer (2002), pode significar uma desvalorização do educador, ao qual bastaria o afeto e o conhecimento do senso comum, por serem o cuidado e educação infantil naturalizados pelas relações de gênero e parentesco.

A referência sendo sempre a família, a mãe pode confundir seu papel com o do educador e competir com ele, assim como imaginar que o cuidado é realizado na creche da mesma forma que o é em casa. Provavelmente, derive daí a fantasia de que as necessidades individuais não sejam atendidas, os educadores não sejam bastante atenciosos e cuidadosos, o filho não se alimente e adoeça. 
Há também uma concepção de criança, socialmente construída, incapaz de relacionar-se com as outras crianças e adultos, além daqueles do meio familiar.

Ah! O primeiro dia foi terrível. Ela chorava. Porque a outra sempre ficou comigo. Então, é a primeira vez que ela sai, eu chorei muito, ela também. No começo ela não queria vir, nossa! Eu ia trabalhar, não via a hora de eu pegar ela, então eu fui acostumando. Eu achava que ninguém ia cuidar dela direito, achava que ela ia ficar sozinha, isolada em um canto; eu achava que ela ia ficar desprezada, era só isso que passava na minha cabeça, num canto triste. Na minha cabeça, era isso, que ninguém ia olhar pra ela... não de "não olhar pra ela", mas deixar sozinha num canto. (Mãe de Tânia, três anos)

As famílias observam outros usuários e trocam impressões enquanto esperam abrir o portão. Às vezes, um comentário ou atitude de outra mãe pode suscitar dúvidas, estranhamentos que reacendem uma desconfiança latente. A evasão de lactentes, pela dificuldade na adaptação ou pelos freqüentes episódios de adoecimento, causa insegurança nas outras mães, podendo ser associado por elas a um "descuido" dos educadores.

Eu só queria saber de outras mães por que colocavam o nenenzinho e tiravam rápido. $\bigcirc$ que acontece, porque as mães tiram? Por que a criança chora? Uma mãe colocou num dia, depois de três dias ela tirou a nenenzinha. Porque ela chorava, ela deixava, saía e ela chorava. (Mãe de André, seis anos; Edílson, quatro anos; Paula, três anos; Dane, dez meses).

As mães com filhos menores de três anos parecem sentir mais insegurança do que aquelas com crianças no pré-escolar, o que se justifica, tanto pela vulnerabilidade biológica e dependência dos cuidados de um adulto como pela aceitação social da idade em que a criança deve ir à escola. Para conferir se os filhos estão com as pessoas certas e em ambiente seguro, algumas mães utilizam estratégias para observá-los depois que os deixam na sala. Esse comportamento pode ser interpretado pelos profissionais como evidência de que a princípio é apenas a necessidade que impõe deixar a criança aos cuidados deles, e só com o tempo a confiança é estabelecida. 
Creche e família...

Ah, eu tinha medo, assim, de não conseguirem fazer ela dormir, de não darem a comidinha pra ela, porque ela é difícil. Ela não vai, na primeira vez que está com fome, comer o que derem pra ela, entendeu? Medo de não terem o tempo e a paciência pra fazer tudo o que eu faria dentro de casa; de balançar, de carregar, de fazer dormir, de tudo, o banho, que ela odeia lavar a cabeça, entendeu, eu morria de medo. (Mãe da Lícia, um ano)

Algumas mães expressam diferentemente as emoções suscitadas ao delegar o cuidado do filho aos profissionais da creche, preferem não acompanhá-lo no processo de adaptação, apostando na capacidade de ele "se acostumar" ao novo ambiente.

A reação da criança ao novo ambiente pode variar com suas características pessoais, idade, atitude do educador, planejamento dos cuidados e a reação dos pais. Os profissionais também têm que lidar com suas emoções nesse momento. Eles precisam que os pais depositem confiança neles para que possam cuidar e educar com autonomia, embora, ao se colocarem no lugar desses pais, reconheçam as dificuldades, principalmente das "mães", no processo.

Porque eu sempre coloquei a minha posição pra elas: Olha, eu sou assim, se eu te falar alguma coisa que te magoa, por favor, você volta e fala para mim porque nós somos seres humanos e nós erramos. Eu gostaria que você depositasse toda a confiança em mim porque seu filho vai ficar comigo doze horas, você precisa me conhecer, gostar de mim, confiar, porque se não vai ser muito difícil. É doloroso para a mãe deixar um filho aqui. (Educadora)

A consciência do seu papel em relação às funções paternas e maternas permite que o educador identifique sentimentos ambíguos das mães que se sentem confiantes quando os filhos demonstram afeto pela equipe e, ao mesmo tempo, temem perder "o lugar especial" que ocupam na vida da criança: "É, quando ela não queria ir embora, como hoje, eu... eu fico... É porque ela gosta também, se ela não gostasse, ela queria ir embora, se ela não quer ir embora é porque ela gosta também" [sorri] (Mãe de Taís, seis anos).

$\bigcirc$ educador também lida com ambigüidades diante das manifestações 
afetivas das crianças, sentindo-se gratificado pelo fato de elas, às vezes, preferirem permanecer na creche e, até mesmo, se identificarem com ele.

Mesmo no grupo da pré-escola, as mães contam: "Ah, ele fala que eu tenho que cortar cabelo e pintar a unha igual a você". Então, tem a questão da identidade! Aí eu explico que é diferente. Aqui a gente brinca, é diferente a relação, mas elas ficam incomodadas. Elas chegam brincando, mas você percebe. Já no grupo de crianças menores, é diferente, elas não têm ciúmes. Por exemplo, a criança tem uma afinidade com o educador, pra elas é bom, porque se eles estão gostando, é porque não está tendo nada de ruim com eles. Como a Nora, eu não podia sair da sala que ela gritava, que ela queria ficar comigo por todo o lugar, e a mãe achava isso muito legal. "Criança é sincera, se ela está gostando é porque não estão maltratando minha filha”. (Educadora)

No momento em que a mãe entrega o filho para o educador, a criança pode se agarrar a ela, o que exige habilidade do profissional para lidar com a situação. A mãe fala de sua dificuldade inicial em entregar a filha à educadora que a retirava "bruscamente" de seu colo. Procurou discutir com a equipe da creche, o que considerava um problema, mas sentiu-se incompreendida, o que afetou, desde então, sua relação com os profissionais.

Logo no começo, embora a Rute gostasse da creche, ela queria que eu ficasse com ela. Então, várias vezes, a educadora me tirou a menina do colo, me arrancou a menina do colo. Aí eu ficava um pouco e depois ia embora, ela chorava um pouco, mas não é que ela não queria ficar não, ela não queria que eu fosse. Então, em uma das reuniões, eu disse que queria falar sobre isto, aí virou um novelo. Todas as mães reclamaram da mesma coisa. Eu não sei se todas as mães foram chamadas ou não, mas eu fui chamada para uma reunião com as educadoras, e de lá pra cá, sinceramente, eu não tenho coragem de falar nada. (Mãe da Rute, três anos)

No final do dia, também pode haver tensão entre o educador, a mãe e a criança, pois esta, da mesma forma que se agarrou à mãe no momento da entrada, pode virar as costas para ela, agarrando-se ao educador. 
Creche e família...

De acordo com Viorst (1986), a criança menor de três anos pode reagir às primeiras separações temporárias de seu ambiente familiar com um comportamento de alheamento, recebendo a mãe com frieza, tratando-a com uma atitude distante e apática, como se estivesse castigando-a por ter partido. $\mathrm{Na}$ perspectiva dos educadores, o desenvolvimento da autonomia e a socialização da criança, mediado pelos profissionais da creche, pode significar uma perda para a mãe. Ao mesmo tempo, na perspectiva da mãe, contar para o educador as manifestações de afeto da criança pode ser uma maneira de garantir o compromisso dele com o retorno deste sentimento.

É uma sensação de perda! Parecia assim que eu estava tomando o lugar dela, como mãe. Por mais que ela tentasse mostrar uma outra coisa, um outro sentimento, mas a gente sabe, que sempre tem aquele medo da mãe, principalmente ciúmes. "Olha, o final de semana inteiro, o fulano falou em você". (Educadora)

À medida que a criança cresce, as expectativas de cuidados e a relação com os educadores modificam-se.

A educadora Teresa sempre foi um pouquinho mais dura. Se bem que eu pedi, pelo amor de Deus, que este ano ela assumisse o módulo em que a Rute está. É uma contradição! [sorri]. Embora eu não concorde com a forma que ela tira a criança do colo da mãe. Porque a Teresa é mais dura, entendeu? Então eu acho que a Rute precisa de um pouco de... A Teresa é bem segura, embora eu não concorde com a forma que ela tira a criança do colo da mãe. É uma contradição, mas... [sorri]. (Mãe de Rute, três anos)

A mesma educadora que foi avaliada pela mãe de Rute como "brusca", no momento de acolhê-la, quando a criança ainda era de colo, é considerada, posteriormente, pela mesma mãe, como adequada por sua "firmeza", qualidade necessária para estabelecer limites para a menina que cresceu.

Ao contrário das mães, a maioria dos pais que acompanham os filhos no processo de adaptação mostra-se mais tranqüila, com preocupações mais genéricas, menos detalhadas em relação aos cuidados da criança. 
Assim, as diferenças de comportamento relatadas e observadas podem ser explicadas pelo papel tradicional do pai de iniciar o filho no mundo extrafamiliar, estimulando sua independência. Para o pai, considerando que é educado em uma sociedade na qual o cuidado da criança é naturalizado como função feminina, talvez, possa ser mais tranqüilo deixar o filho sob os cuidados de outros, sobretudo, quando este outro é uma mulher.

Entretanto, há casos em que o pai se mostra tão ou mais ansioso que a mãe. Houve dois casos em que se evidenciaram, posteriormente, relações problemáticas entre pai-mãe-filha, afetando inclusive a saúde da criança. Assim, segundo Butler (2003, p.24), se o gênero são os significados culturais assumidos pelo corpo sexuado, não se pode dizer que ele decorra de um sexo, desta ou daquela maneira.

Para homens e mulheres, o fato de o filho já ter freqüentado outra creche pode ser tanto um aspecto facilitador como o contrário, dependendo de como foi a vivência pregressa. Apesar das diferenças de gênero e grau de parentesco com a criança, para pais, mães, avós, irmãos, tios, o processo de aquisição de confiança é lento e variável, dependendo da história pessoal, valores, expectativas de cada família, e de como os profissionais da creche percebem essas peculiaridades e lidam com elas.

O mais difícil é você criar o vínculo com a mãe. Você tem que ter muita paciência. O que eu costumo comentar, é que você tem sempre que respeitar a mãe. Muitas vezes, ela tem conceitos, crenças, que a gente não concorda, mas você também deve saber como dizer não para ela. (Técnica de enfermagem)

Respeitar o direito das crianças, ao mesmo tempo, a perspectiva dos pais e deixar claros os limites do contexto coletivo, torna complexa a relação entre profissionais e famílias. A equipe percebe as dificuldades e vai lidando com cada família, tendo de enfrentar os seus próprios sentimentos de rejeição inicial em relação às suas peculiaridades.

A primeira abordagem com os pais é sempre difícil. Eu percebi que dependendo da forma como eu os recebo e conduzo a entrevista, eles agem comigo. Têm aqueles que eu olho e já sinto antipatia, sabe. Mas eu passo por cima disso, 
Creche e família...

porque temos que ser profissionais. As pessoas que eu sinto uma antipatia inicial, depois são as que eu mais gosto, engraçado isso. Então quando eu as recebo, cumprimento, falo quem eu sou, falo "fique à vontade", brinco, aí elas agem normalmente comigo, apesar de que têm aqueles que não têm jeito. (Técnica de enfermagem)

Procurar compreender os motivos dos conflitos iniciais ou posteriores possibilita que as primeiras impressões sejam atualizadas e a relação possa fluir. Um conflito não explícito e não resolvido pode dificultar cada vez mais a relação, apesar de a criança reagir de forma diferente, mostrando alguma autonomia em relação ao comportamento dos pais.

Quando o pai fez a matrícula do Wilson, no lugar do registro de nascimento, ele me entregou o RG da criança. Passou um tempo, eu estava conferindo todas as pastas e vi que não tinha a certidão, não lembrei que tinha o RG e pedi para o pai. Nossa! Ele voou pra cima de mim7, falou um monte. Eu falei assim: claro, eu percebi que houve uma falha e estou tentando reparar. Ele falou que eu não tinha responsabilidade, que não sei o quê! Desde esse dia ele virou a cara pra mim, não conversa, dificilmente ele me cumprimenta. Mas o Wilson me cumprimenta, fala: "Bom dia! Boa tarde!", cumprimenta todo mundo que passa ao lado dele, diferente do pai, por qualquer coisinha que acontece vira a cara. (Técnica de enfermagem)

Como todas as relações humanas em que há compartilhamento de ações visando a um objetivo comum, a relação dos profissionais com a família se constitui gradativamente, permeada por contradições, na lida cotidiana com os cuidados e a educação das crianças.

É complicado, porque você bate o olho, quem vê cara não vê coração. Mas quando eu entrei... você sempre tem receio de deixar um filho na mão de outra pessoa. Você não sabe, quais os princípios que aquelas pessoas têm, você não conhece as normas diretivas que vão ajudar na formação do seu filho, é difícil, você não tem essa noção, é só o tempo. É como o casamento. (Pai de Juliana, dois anos) 


\section{OS CONFLITOS}

As famílias diferem em sua relação cotidiana com os profissionais. Algumas seguem as regras de funcionamento sem questionar, outras reclamam, "há mães que burlam as normas ou mentem", conforme refere a diretora que atribui "a relação confusa" de uma delas aos problemas enfrentados pela família. Se, por um lado, a reclamação da peça de roupa perdida é legítima, por outro, a tentativa de burlar a regra sobre doenças transmissíveis, ou o horário de chegada e saída das crianças, revela as dificuldades de algumas famílias lidarem com os limites impostos pelo contexto coletivo.

Não gosto desta mãe, ela mente, joga no meio, principalmente, quando chega atrasada. Quando o menino estava com catapora, ela colocou-o no módulo e saiu correndo. Uma vez perdeu uma calça, apesar deles orientarem para colocar o nome, e passou o ano inteiro perguntando se a calça apareceu. Ela diz que o patrão anda reclamando que o menino fica doente, tem problemas em casa e o marido está desempregado. Quando ele estava empregado a relação com a creche era melhor. Mas é uma relação muito confusa! (Diretora)

Os profissionais também são pessoas com valores, peculiaridades, preferências e dificuldades que precisam ser elaboradas para que se relacionem de forma profissional com as diferentes famílias. Criar vínculos profissionais não é o mesmo que criar vínculos pessoais.

É um exercício muito grande o de você separar, fazer o seu papel. As mães gostam de conversar, e eu gosto de sentar com elas e jogar conversa fora, de falar do tempo, das outras coisas, falar de novela e tal, mas com ela não. Com essa, eu atendo, com a mesma diligência que eu atendo os outros, só que não é além das vísceras, entendeu? Eu não tenho nenhum afeto, eu tenho respeito, tenho respeito como ser humano, como uma usuária da creche. Mas, por exemplo, assim, se fôssemos fazer um amigo secreto eu ia fazer de tudo pra rasgar o papel e não tirá-la entendeu? Preferiria tirar a mãe da Rute, com toda aquela coisa chata que ela tem. (Diretora)

As impressões de um profissional da creche a respeito de um pai ou mãe 
Creche e família...

parecem generalizar-se entre a equipe, talvez pelos comentários internos, talvez pelo tipo de relação que a família estabelece com todos.

As diversas famílias podem ter religião, conhecimentos, valores e condições de vida diferentes que repercutem no jeito que cuidam das crianças, sendo que os principais conflitos incidem nos cuidados com a alimentação e higiene (Maranhão, 2005).

Eu pensava assim: "Nunca vou colocar meus filhos lá, imagina, eles vão pegar piolho". Eu discriminava mesmo, eu nem sei por que eu fazia aquilo. Depois que meus sobrinhos vieram pra cá, eu vi que aqui era bem diferente da escola que eu pagava R\$ 1.200,00 por mês; aqui o cuidado e a parte educativa era bem melhor. (Mãe de Ana Cláudia, quatro anos)

A inserção de crianças com melhores condições econômicas também torna diferentes as demandas e a forma como as famílias lidam com as regras institucionais. As famílias de estratos médios da população, que outrora não eram usuárias de creche pública, cada vez mais passam a fazê-lo, tanto pela perda de poder aquisitivo como pela superação de preconceitos sobre a creche. Essas famílias são culturalmente mais exigentes e menos subservientes do que as famílias mais pobres, o que significa novos desafios para a relação entre profissionais e usuários.

Só que eu vim com as regalias que eu tinha na outra escola. Assim, eu chegava no horário que eu queria, mesmo que fosse fora de horário e os funcionários tivessem indo embora eu estava chegando. Tudo bem, eu não fazia isso de propósito, porque a empresa tinha acabado de ser privatizada e eu trabalhava até tarde. Então, às vezes, eu vinha pegar as crianças uma hora depois do horário de encerramento das atividades da creche. (Mãe de Ana Cláudia, quatro anos)

Algumas famílias, identificadas com uma condição social mais favorecida e, portanto, predispostas a um tratamento de qualidade, confundem o direito (universal) ao serviço público de boa qualidade com o "seu" direito, personalizando-o e desrespeitando freqüentemente regras coletivas, o que pode ser interpretado como imprecisão dos limites entre o público e o privado, conforme formulação de Da Matta (1986). Essa atitude é encontrada em camadas 
sociais que buscam se diferenciar exigindo um tratamento "privado", que nega a universalidade do direito ao atendimento público, levando a lógica personalista que preside as relações no mundo privado para o mundo público. $\bigcirc$ que deveria ser um direito universal transforma-se, mais uma vez, num favor, que remete a uma condição particular.

Em uma primeira conversa informal a mãe referida disse à pesquisadora que fora "disciplinada pela creche". $\bigcirc$ uso desta expressão poderia sugerir o conceito de disciplina de Foucault ( 1979, 1987) - o exercício do poder por meio da coerção sutil, ininterrupta, constante, impondo um rigoroso código que normatiza o tempo, o espaço e os movimentos, visando à "docilização dos corpos". O sentido dado ao termo, entretanto, remete a outro significado. Ela referia-se a uma prática adquirida no contato com a creche, ao ser chamada a refletir sobre os cuidados infantis, baseados na perspectiva dos educadores que compartilham os cuidados e a educação de seus filhos. Há um limite tênue entre a atitude normativa por parte da equipe e a negociação entre equipe e família de valores, crenças, conhecimentos e hábitos distintos e que afetam diretamente o cuidado das crianças.

Achava que eu dando bens materiais, eu estava suprindo a minha presença. Então, eu dava muito, presentes, brinquedos, passeios, mas a minha presença era pouca, até que a diretora da creche me chamou. Aí ela me falou um monte de coisa que a princípio eu achei que foi um atrevimento fora do comum, nunca ninguém falou dessa maneira comigo. Até então, eu me achava um exemplo de mãe, sabe, a mãe perfeita! Depois que ela falou tudo aquilo, eu fui me disciplinando. Fui vendo que ela tinha razão. Aí, eu comecei a disciplinar com a alimentação. Eu dava lanche todo dia, então, eu comecei a prestar atenção na alimentação, no dia-a-dia do meu filho, nos horários, ver a dificuldade das outras pessoas. Não que eu fosse uma pessoa egoísta, nada disso, mas eu achava que a dificuldade só atingia os outros, a mim, não! Eu era inatingível. Então, a creche pra mim foi uma lição de vida e, hoje, quando eu penso que a minha filha já vai sair daqui! Eu já estou sofrendo antecipadamente. (Mãe de Ana Cláudia, quatro anos)

Os profissionais também têm que lidar com as contradições que as diferenças sociais evidenciam, até mesmo em uma mesma família. 
Creche e família...

A diferença era muito gritante. Na sala tinha muitos casos estranhos, uma mãe que não tinha condições nenhuma, nenhuma mesmo. E têm as diferenças entre mães que são irmãs. Dá um dó ver o jeitinho dela, a mãe mais pobre deixa a filha um pouco pra escanteio. Às vezes, ela vem a semana inteira com uma roupa, e a prima toda bem arrumadinha sabe, e a roupa que a Ana Cecília usava era roupa velha, que não servia para a Ana Cláudia ou que ela não queria mais. Nossa, ver uma situação dessa, eu não gosto, isso é uma coisa que me aborrece! (Técnica de enfermagem)

Os profissionais estranham e necessitam lidar tanto com os valores e as práticas das famílias mais pobres como daquelas consideradas "diferenciadas". As maiores dificuldades de compartilhar cuidados encontram-se nos extremos da hierarquia social.

Embora a creche venha tentando superar o estigma de instituição para crianças pobres, existem muitas contradições nesta prática, evidenciadas, por exemplo, na fala da coordenadora pedagógica que expressa achar "engraçado" que, "não precisando", algumas famílias sejam usuárias da creche. Sua atitude reflete a ambigüidade quanto ao reconhecimento do cuidado e da educação da criança pequena como funções que requerem serviços de qualidade, para além das funções maternas e paternas desempenhadas no âmbito privado.

\section{CONSIDERAÇÕES FINAIS}

A relação entre profissionais e famílias constitui-se gradativamente, permeada por afinidades e contradições, na lida cotidiana com as crianças. A complexidade dessa relação foi confirmada pelas evidências de que por ela perpassam questões de várias ordens: gênero, direitos sociais, organização e integração de serviços para a infância, desigualdade socioeconômica, diversidade cultural dos usuários, formação dos profissionais de educação infantil e de saúde.

Embora não se possa negar totalmente que o modelo disciplinador, no sentido foucaultiano, permeie, de alguma maneira, a prática dos profissionais, a evidência dos conflitos pode ser a expressão de que as famílias e os profissionais encontram espaço para expor suas insatisfações e negociar as regras, limites e acordos necessários ao processo de compartilhar educação e cuida- 
do infantil. Os conflitos são inerentes à vida social e psíquica e sua ausência pode significar apatia e submissão de uma das partes e sua não explicitação pode resultar em violência (Galvão, 2004).

Compartilhar cuidados implica o encontro de famílias e profissionais que podem ter perspectivas diferentes sobre desenvolvimento e necessidades infantis, o que demanda uma constante negociação entre as partes. No entanto, é preciso considerar, sobretudo, a perspectiva da criança, foco do cuidado e, ao mesmo tempo, participante ativa da relação entre sua família e os profissionais de educação infantil.

\section{REFERÊNCIAS BIBLIOGRÁFICAS}

AMORIM, K. S. et.al. Processos de adaptação de bebês à creche. In: ROSSETTI-FERREIRA, M. C. et al. (orgs.) Rede de significações e o estudo do desenvolvimento humano. Porto Alegre: Artmed, 2004. p. I37-56.

AMORIM, K. S.; ROSSETTI-FERREIRA, M. C. A Matriz sócio-histórica. In: ROSSETTIFERREIRA, M. C. et al. (orgs.) Rede de significações e o estudo do desenvolvimento humano. Porto Alegre: Artmed, 2004. p.93-I 12.

BONOMI, A. O Relacionamento entre educadores e pais. In: BONDIOLI, A.; MANTOVANI, S. (orgs.) Manual de educação infantil de 0 a 3 anos: uma abordagem reflexiva. 9.ed. Porto Alegre: Artmed, 1998. p. 161-72.

BRASIL. Leis e decretos. Constituição da República Federativa do Brasil. Brasília, 1988.

BUTLER, J. Problemas de gênero: feminismo e subversão da identidade. Rio de Janeiro: Civilização Brasileira, 2003.

CAMPOS, M. M. A Legislação, as políticas nacionais de educação infantil e a realidade: desencontros e desafios. In: MACHADO, M. L. A. (org.) Encontros e desencontros em educação infantil. São Paulo: Cortez, 2002. p.27-33.

CHODOROW, N. Psicanálise da maternidade: uma crítica a Freud a partir da mulher. Rio de Janeiro: Rosa dos Tempos, 1978.

DA MATTA, R. Cidadania: a questão da cidadania num universo relacional. São Paulo: Brasiliense, 1986. A Casa e a rua, p.55-80.

FONSECA C. Os Caminhos da adoção. São Paulo: Cortez, 1995.

FOUCAULT, M. Microfísica do poder. I6.ed. Rio de Janeiro: Graal, 1979. 
Creche e família...

. Vigiar e punir: história da violência nas prisões. Petrópolis: Vozes, 1987.

FRANCISCATO, I. As Famílias das crianças atendidas pela creche segundo a ótica de seus profissionais. São Paulo, 1996. Dissert. (mestr.) Pontifícia Universidade Católica de São Paulo.

GALVÃO, I. Cenas do cotidiano escolar: conflito sim, violência não. São Paulo: Vozes, 2004.

HADDAD, L. A Relação creche família: relato de uma experiência. Cadernos de Pesquisa, n.60, p.60-78, fev. 1987.

Substituir ou compartilhar? O papel das instituições de educação infantil no contexto da sociedade contemporânea. In: MACHADO, M. L. A. (org.) Encontros e desencontros em educação infantil. São Paulo: Cortez, 2002. p.91-103.

HADDAD, L. Direito humano à educação. In: LIMA JR., J. B. (coord.) Plataforma brasileira de direitos humanos econômicos, sociais e culturais (DhESC): relatório brasileiro sobre direitos humanos econômicos, sociais e culturais 2003. Recife: Bagaço, 2003. p. $199-252$.

INGROSSO, M. ServiçOs para a infância e para as famílias entre regulamentação e inovação. In: BONDIOLI, A; MANTOVANI, S. (orgs.) Manual de educação infantil de 0 a 3 anos: uma abordagem reflexiva. 9.ed. Porto Alegre: Artmed, 1998. p.58-72.

KRAMER, S. A Formação do profissional de educação infantil: questões e tensões. In: MACHADO, M. L. A. (org.) Encontros e desencontros em educação infantil. São Paulo: Cortez, 2002. p. $117-32$.

MALINOWSKI, B. Objeto, método e alcance desta pesquisa. In: GUIMARÃES, A. Z. (org.) Desvendando máscaras sociais. 2.ed. Rio de Janeiro: Francisco Alves, 1980. p.39-6I.

MARANHÃO, D. G. O Cuidado como elo entre a saúde e a educação. Cadernos de Pesquisa, n. II I, p. II 5-33, dez. 2000.

O Cuidado compartilhado: relações entre famílias e profissionais de uma creche. São Paulo, 2005. Tese (dout.) Programa de Pós-Graduação em Enfermagem, Universidade Federal de São Paulo.

O Processo saúde-doença e os cuidados com a saúde na perspectiva dos educadores infantis. Cadernos de Saúde Pública, n. 16, p. I |43- | | 48, 2000a.

MONÇÃO, M. A. G. Subalternidade ou parceria? Um estudo das representações sociais sobre a participação das famílias nas creches. São Paulo, 1999. Dissert. (mestr.) Pontifícia Universidade Católica de São Paulo.

MORAES, L. Q. Infância e cidadania. Cadernos de Pesquisa, n.91, p.23-30, nov. 1994.

ROSEMBERG, F. Educação formal e mulher: um balanço parcial da bibliografia. In: COSTA, 
A. O.; BRUSCHINI, C. (orgs.) Uma questão de gênero. Rio de Janeiro: Rosa dos Tempos; São Paulo: Fundação Carlos Chagas, 1992. p. I5I-82.

ROSSETTI-FERREIRA, M. C.; AMORIM, K. S.; VITÓRIA, T. Integração família e creche: o acolhimento é o princípio de tudo. In: MATUANO, E. M.; LOUREIRO, S. R.; ZUARDI, A. W. (orgs.) Estudos em saúde mental. Ribeirão Preto: FMRP/USP, I997. p. 107-31.

SCAVONE, L. Saúde e gênero: impactos na família das doenças profissionais causadas pelo uso do amianto. In: OLIVEIRA, E. M.; SCAVONE, L. (orgs.) Trabalho, saúde e gênero na era da globalização. Goiânia: AB, 1997. p.39 - 50.

SAFFIOTI, H. I. B. Rearticulando gênero e classe social. In: COSTA, A. O.; BRUSCHINI, C. (orgs.) Uma questão de gênero. Rio de Janeiro: Rosa dos Tempos; São Paulo: Fundação Carlos Chagas, 1992. p. I83-215.

SARTI, C. A. A Assimetria no atendimento à saúde: quem é o necessitado? [Apres. ao $20^{\circ}$ Encontro Anual da Associação Nacional de Pós-Graduação e Pesquisa em Ciências Sociais, 27-3 I out. 1998, Caxambu].

A Família como espelho: um estudo sobre a moral dos pobres. 3.ed. São Paulo: Cortez, 2005.

Família e individualidade: um problema moderno. In: CARVALHO, M. C.

B. (org.) A Família contemporânea em debate. 2.ed. São Paulo: Educ, Cortez, 1995. p.39-49.

VIORST, J. Perdas necessárias. 20.ed. São Paulo: Melhoramentos, 1986.

Recebido em: março 2006

Aprovado para publicação em: junho 2007 